\title{
Aleiodes (Hymenoptera, Braconidae, Rogadinae) diversity in Washington U.S.A. including three new species
}

\author{
JOSEPH FORTIER \\ Department of Biology, Wenatchee Valley College, 116 W. Apple Way, Omak, WA 98840 \\ इ"josephfortier@gmail.com; @ ittps://orcid.org/0000-0002-7767-5490
}

\begin{abstract}
Aleiodes Wesmael is a large cosmopolitan genus of endoparasitoid wasps that is evidently especially speciose in the Western Hemisphere based on numbers of described species. As with most diverse insect groups, relatively little is known about Aleiodes species diversity and biology. Here I summarize what is known about Aleiodes diversity in Washington State and contiguous Inland Northwest states and province, and I report three new species recently collected by malaise trap sampling for Aleiodes in Okanogan County, WA: Aleiodes khalafi, Aleiodes okanoganensis, and Aleiodes quasiburrus. Given the number of new species (three) and first records of previously described species (two) in Washington elucidated by this study, there is evidently much work to do to reach a fair estimate of Aleiodes species diversity in the Inland Pacific Northwest.
\end{abstract}

Key words: mummy, morphology, malaise trap, sclerite sculpturing, species-group

\section{Introduction}

With about 17,000 described species and an estimated actual species richness of 31,000 to 51,000 species globally (Jones et al., 2009), the wasp family Braconidae, which consists of larval parasitoids mostly of other holometabolous insects (Quicke, 1997), is the second largest family within Hymenoptera, even though it remains poorly known (Jones et al., 2009).

The genus Aleiodes is a large group of braconids, comprising about 225 described species worldwide (DelfinGonzalez \& Wharton, 2002) of which 212 are New World species and of these, about 143 species occur in the Nearctic (Shimbori et al., 2015). Aleiodes species may be identified as belonging to this genus by the following combination of characters: (1) labrum visible and concave, forming a mouth-like area (Figure 1B), (2) first metasomal tergite sculpturing with an anterior-medial polished, triangular area that narrows posteriorly into a median carina running the length of the tergite, (3) second metasomal tergite with parallel, longitudinal running ridges (carinae) (Figure 2A), and (4) the female ovipositor sheath short, widened, and flattened (Figure 3B). Variations in Aleiodes morphology across the genus that can be used to distinguish species include color, body size, wing venation pattern, number of antennal segments, shape of antennal segments, surface sculpturing patterns on various sclerites, and size ratios between various body parts.

Aleiodes are endoparasitoids of lepidopteran larvae. The Aleiodes larva mummifies the host larva when it dies, and then pupates inside the mummy. The mummy is the hardened remains of the skin of the host last larval instar. Before pupating, the Aleiodes larva usually cuts a hole in the ventral thoracic region of the host mummy through which the mummy is glued to a substrate (leaf, twig, etc.). Upon emergence, the adult Aleiodes cuts a smooth, round hole in the dorso-posterior area of the mummy through which to exit (Figure 4, arrow) (Shaw 1997).

The Inland Northwest U.S. is a relatively underexplored region of the world with respect to Aleiodes as well as to other groups of insects. The purpose of this work is to investigate Aleiodes species richness in eastern Washington U.S.A. and contiguous areas, including undescribed species, range information from taxonomic literature, and new range information for previously described species. All Aleiodes species reported to date in Washington, including new species here, are tabulated with host information where host information is known. Descriptions of three new species are also provided. 

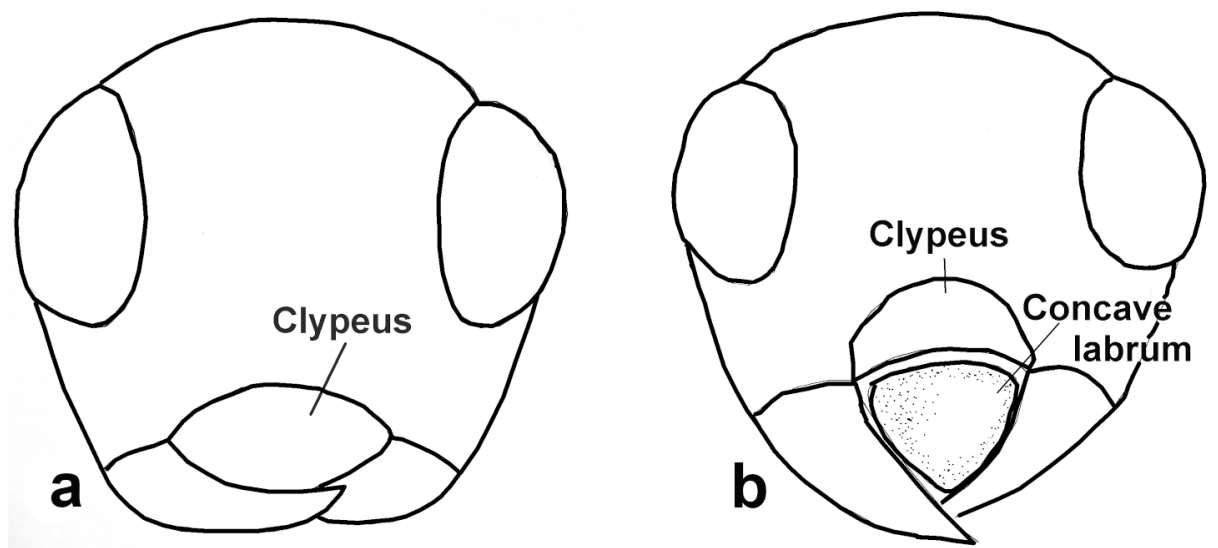

FIGURE 1. Faces of Braconidae. a: Normal condition. Clypeus extending to mandibles or partly over them. b: Cyclostome condition present in Aleiodes. Clypeus is arched over concave labrum forming a mouth-like structure.

\section{Methods}

On July 4, 2015, a female Aleiodes specimen was collected by hand near Inchelium Center, Ferry County, Washington before this research plan was begun. The habitat type surrounding the site of collection is Ponderosa pine and Douglas fir forest.

On September 1, 2019 and June 1, 2020, a malaise trap was assembled on hillsides over a moist drainage west of Omak Lake, Okanogan County, Washington. The habitat type in the area is ponderosa pine and sagebrush steppe. The trap location site in 2019 (site 1) was on a west-facing hillside at $48^{\circ} 18^{\prime} 13^{\prime \prime} \mathrm{N} ; 119^{\circ} 26^{\prime} 44^{\prime \prime} \mathrm{W}$. The trap location site in 2020 (site 2) was on a nearby opposite east-facing hillside at $48^{\circ} 18^{\prime} 08^{\prime \prime} \mathrm{N} ; 1^{\prime} 19^{\circ} 26^{\prime} 46^{\prime \prime} \mathrm{W}$. The site 1 trap was set up on September 1, and the sampling bottle was collected on September 18. The site 2 trap was set up on June 1, and the sampling bottle was collected on June 10, June 30, and July 26. On August 10 it was discovered that a bear had destroyed the trap, and there was no sample to collect.

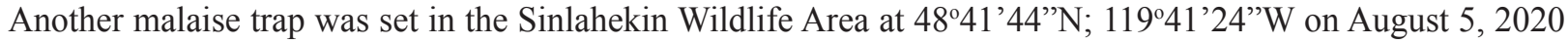
(site 3) in wooded habitat (Ponderosa pine). When it was checked on August 18, it was found burned by a recent wildfire. The sample was unharmed and collected.

On July 24, 2020, a malaise trap was set in Sinlahekin Wildlife Area at 48.39'48” N; 11941'26”W (site 4), in cottonwood-aspen forest. The sampling bottle was collected on August 4, August 18, September 1, and September 22 , 2020. Another malaise trap was set near Conconully, WA at $48^{\circ} 33^{\prime} 28 \mathrm{~N} ; 119^{\circ} 47^{\prime} 51^{\prime \prime} \mathrm{W}$ (site 5) on August 21 , 2020. It was collected on September 4, September 14, and October 12.

Identification of all Aleiodes specimens was made by the author, using a Leica LZ12.5 stereomicroscope, the published identification keys and species descriptions in Marsh and Shaw 2001 and Shaw et al. 2006. All images were taken using a Nikon 7500 camera with a Nikkor AF-S DX Micro $85 \mathrm{~mm}$ f/3.5G ED VR macro lens enhanced with combined $36 \mathrm{~mm}$ and two $-20 \mathrm{~mm}$ extension tubes.

Terms used for sclerite sculpturing follow Harris (1979), while those used for sclerite and appendage names follow Huber and Sharkey (1993). Wing venation terminology (Figure 5) follows Fortier (2009).

\section{Results}

Only sampling sites one and two yielded Aleiodes specimens. The site one sample yielded four male Aleiodes specimens. The site two sample collected June 10, 2020 yielded 10 Aleiodes specimens. One specimen was collected on June 24 (Table 1).

Table 2 shows previously described and reported Aleiodes species from in and near Washington, new Washington records of previously described species, and new species reported here for the first time. Table 3 provides a tabulation of distinguishing character states for Aleiodes species similar to new species presented here. Aleiodes quasiburrus can be distinguished from specimens recorded in Table 2 by other character states (see discussion). 
TABLE 1. Location sites and dates of Aleiodes collections. Inchelium site: $48^{\circ} 18^{\prime} 50^{\prime \prime} \mathrm{N} ; 118^{\circ} 13^{\prime} 16^{\prime \prime} \mathrm{W}$. Site 1: 48 $18^{\prime} 13^{\prime \prime}$

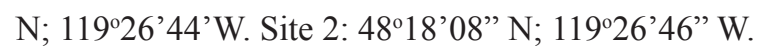

\begin{tabular}{|c|c|c|c|}
\hline Site & Collection date & Species & Number specimens \\
\hline Inchelium & July 4, 2015 & A. medicinebowensis & 1 \\
\hline Site 1 & Sept. 18, 2019 & A. quadratus & 4 \\
\hline Site 2 & June 10,2020 & A. autographae & 2 \\
\hline Site 2 & June 10,2020 & A. okanoganensis & 1 \\
\hline Site 2 & June 10,2020 & A. quasiburrus & 6 \\
\hline Site 2 & June 10,2020 & A. khalafi & 1 \\
\hline Site 2 & June 24, 2020 & A. khalafi & 1 \\
\hline
\end{tabular}

TABLE 2. Aleiodes Wesmael species records in or within areas adjacent to Washington State. Aleiodes species previously reported in Washington and nearby (Marsh and Shaw 2001, Shenefelt, 1978).

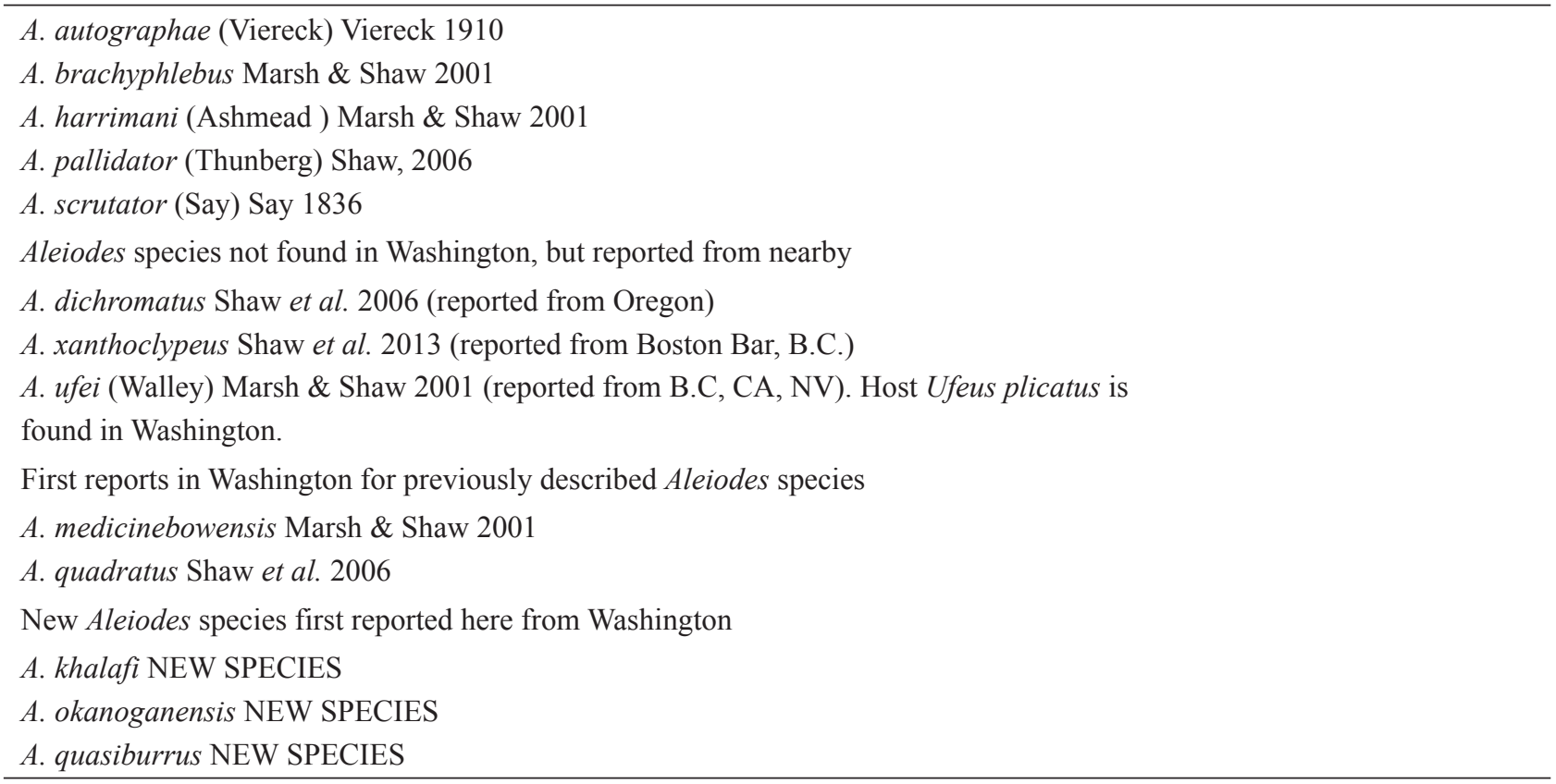

\section{Systematics}

\section{Aleiodes khalafi Fortier NEW SPECIES}

(Figures 6-8)

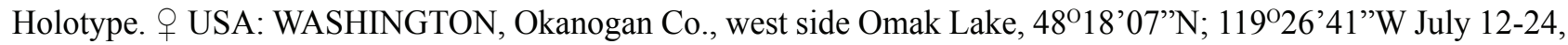
2020, J. Fortier coll. Deposited in NMNH.

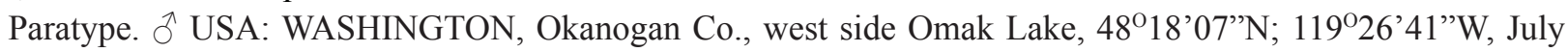
1-10, 2020, J. Fortier coll. Deposited in NMNH

Female. Body color: orange except black on ocellar triangle, mesonotal lobes, basal half of propodeum, ovipositor sheaths and hypopygium, third metasomal tergite and those posterior, tips of mandibles; maxillary palps orange, antennae orange basally becoming dark brown apically, stigma black except orange basally, wing veins mostly black except $\mathrm{C}+\mathrm{Sc}+\mathrm{R}$ orange. Body length: $5.5 \mathrm{~mm}$. fore wing length: $4 \mathrm{~mm}$. Head: ocelli smaller than ocell-ocular distance; 52 antennomeres, all longer than wide, malar space more than twice as long as basal width of mandible, face rugose, frons, vertex rugose. Legs: dorsal side of hind coxa coriaceous, tarsal claws not pectinate, inner hind tibial spur about 0.25 length of hind basal tarsomere. Wings: second submarginal cell small, trapezoidal, vein $\mathrm{r}$ about 0.6 length of $3 \mathrm{RSa}$, 3RSa about 0.8 length of $2 \mathrm{M}$, vein $1 \mathrm{cu}-\mathrm{a}$ distal of $1 \mathrm{M}$ by a distance greater than length of $1 \mathrm{cu}-\mathrm{a}$, hind wing RS recurved, marginal cell narrowest in middle, m-cu pigmented, about 0.5 length of 2r-m. m-cu present, faintly infuscate. Mesosoma: Pronotum coriaceous medially, rugulose laterally; mesonotum 
coriaceous, widely, irregularly spaced costulae running antero-posteriorly, notaulus scrobiculate, terminating posteriorly in rugose posterior area of scutum; scutellum coriaceous rugulose; mesopleuron rugose except for raised medial area minutely rugulose anteriorly, otherwise smooth-shiny; propodeum rugose dorsally, coriaceous costate laterally, median carina weakly complete, becoming weak, wavy in posterior half. Metasoma: First and second tergites rugocostate, median carina complete, first tergite length greater than apical width; third and * fourth tergite rugulocostulate except posterior 0.2 of tergite length smooth and shiny, median carina incomplete, terminating anterior to shiny area on third tergite, faintly present in basal 0.2 of fourth tergite.

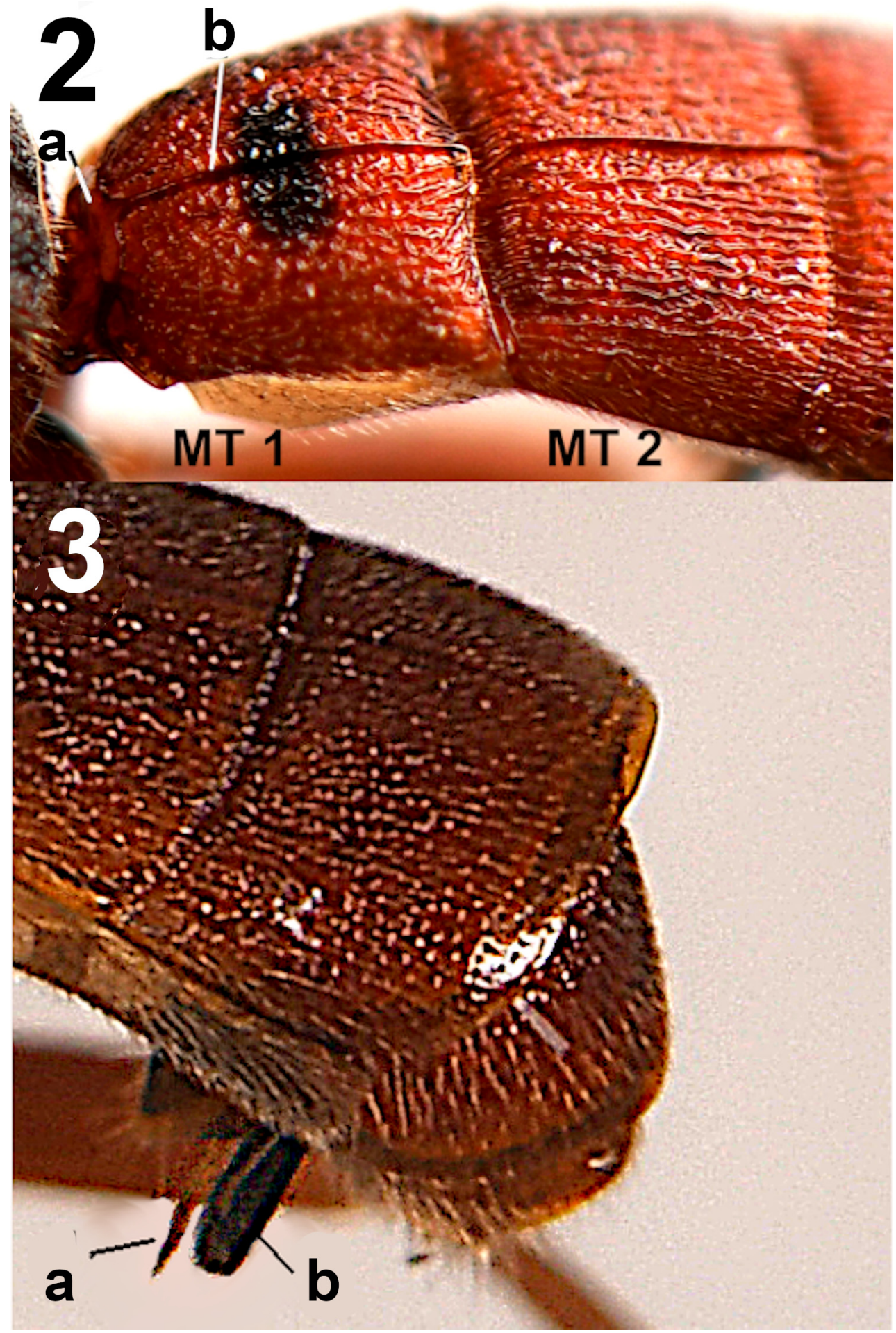

FIGURES 2 \& 3. Characteristics of genus Aleiodes. Figure 2. First and second metasomal tergites of A. okanoganensis. a. basal triangle. b. median carina. Note the costate carinae on the second metasomal tergite. MT I: first metasomal tergite; MT II: second metasomal tergite. Figure 3. Female genitalia of Aleiodes okanoganensis. a. ovipositor. b. ovipositor sheath. Compared to many other parasitoid wasps, these structures are short in Aleiodes, adapted for attacking surface feeding Lepidoptera larvae. 


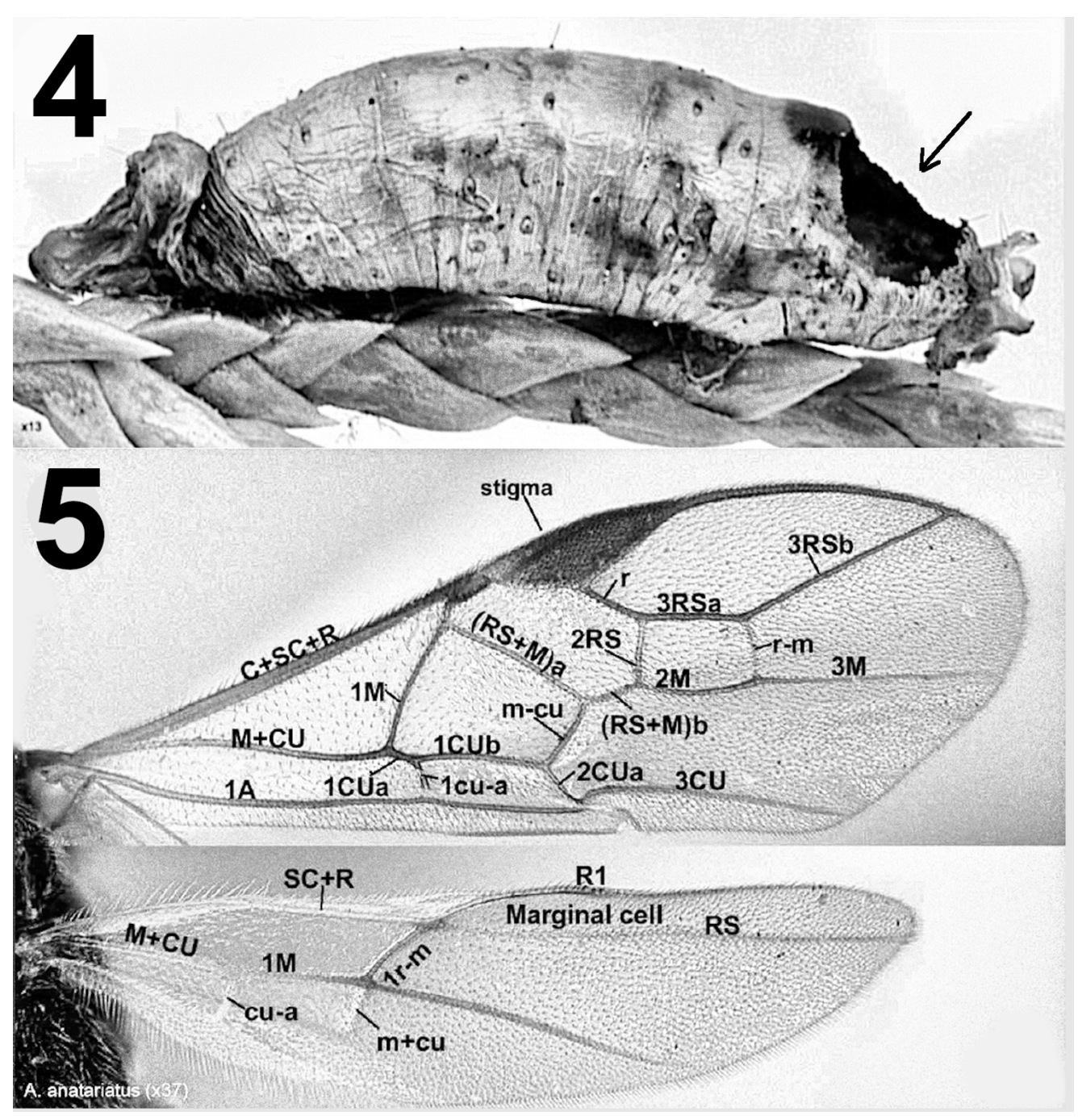

FIGURES 4, 5. Characteristics of Aleiodes. Figure 4. Mummy of Aleiodes (Tetrasphaeropyx) reisi Fortier host (Fortier, 2009). The host mummy of Aleiodes is the hardened, thickened skin of the last larval host instar. When the Aleiodes larva completes its larval development inside the body of the lepidopteran larval host, it kills the host and pupates inside the mummy. The arrow indicates the exit hole cut by the emergent adult wasp. Figure 5. Aleiodes wings (Fortier, 2009), showing abbreviations for names of veins. Cells are regions bordered by veins. The marginal cell of the hind wing is labeled with the full name.

Male. As in female except mesonotal lobes and entire propodeum orange, third metasomal tergite without black, length of first metasomal tergite equal to apical width.

Biology. Host unknown.

Distribution. Known only from type locality in Okanogan County, Washington.

Comments. This species is closely similar to Aleiodes shenefelti Marsh and Shaw. Females share the elongate $1^{\text {st }}$ metasomal tergite with that species. It can be distinguished from that species by the rugulocostulate sculpturing on the $4^{\text {th }}$ metasomal tergite, in contrast to the coriaceous sculpturing on the $4^{\text {th }}$ metasomal segment of $A$. shenefelti.

Etymology. This species is named after Dr. Kamel Khalaf, the author's first entomology professor.

\section{Aleiodes okanoganensis Fortier, NEW SPECIES}

(Figures 2, 3, 9, 10)

Holotype. $q$ WASHINGTON, Okanogan County, west side of Omak Lake, 48 $18^{\prime}$ '07'N; 119²6'41' W, June 1-10, 2020, J. Fortier. Deposited in NMNH. 


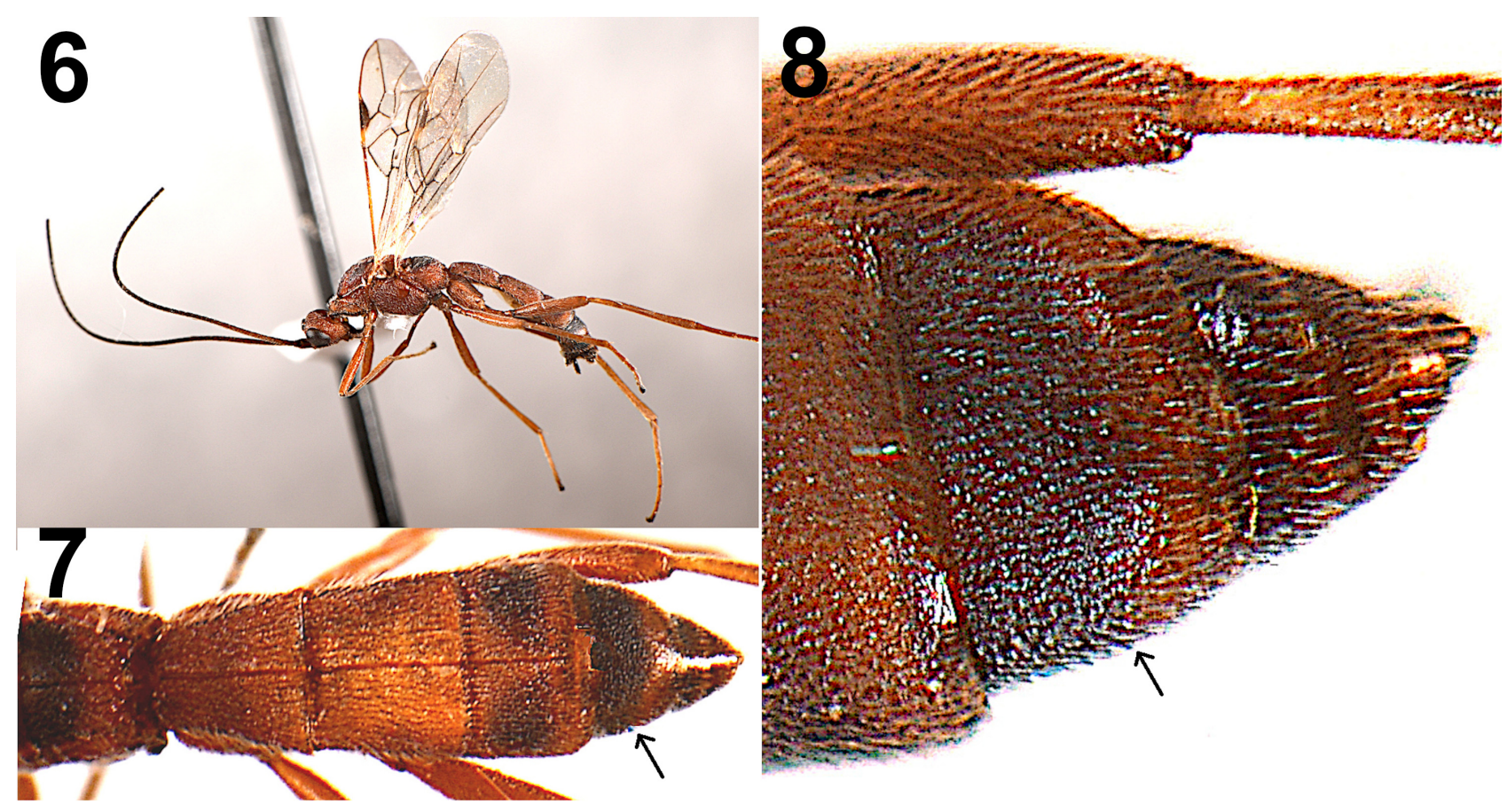

FIGURES 6-8. Aleiodes khalafi (female) NEW SPECIES. Figure 6. Habitus. Figure 7. Dorsal view showing sculpturing of propodeum (pr) and metasomal tergites. Figure 8. Closeup of fourth metasomal tergite (arrow). Note that fourth metasomal tergite is sculptured and is much larger than succeeding posterior tergites. These character states together are unique to species in the Aleiodes coxalis (Spinola) species-group.

Female. Body color: Body nearly entirely orange except black ocellar triangle, black on apex of clypeus and areas of face lateral to clypeus, black maxillary and labial palps and tips of mandibles, antennae orange basally grading to black apically, black dorso-posterior area of mesopleuron just below subalar sulcus, black mesosomal venter, propodeum, and black patch on medial area of first metasomal tergite, ovipositor sheaths and hypopygium black, wings slightly infumate, fore wing veins brown, stigma bicolored, black except orange on basal tip, hind wing veins brown. Body length: $6.0 \mathrm{~mm}$; Forewing length: $5.0 \mathrm{~mm}$. Head: ocelli smaller than ocell- ocular distance; 45 flagellomeres, flagellomeres all slightly longer than wide; malar space over twice as long as base of mandible; face rugose-areolate; frons and vertex rugose. Legs: Dorsal side of hind coxa coriaceous basally, with transverse carinae dorsally, tarsal claws not pectinate, inner tibial spur of hind leg about $1 / 3$ length of basal tarsomere. Wings: fore wing vein $\mathrm{r} 0.6$ length of 3RSa, second submarginal cell trapezoidal, 3RSa 1.2 length of $2 \mathrm{M}$, vein 1cu-a distal of $1 \mathrm{M}$ by a distance greater than length of $1 \mathrm{cu}-\mathrm{a}$, hind wing RS recurved, marginal cell narrowest in middle, m-cu pigmented, about 0.5 length of $2 \mathrm{r}-\mathrm{m}$. Mesosoma: pronotum rugose; mesonotum coriaceous, notauli scrobiculate, complete to postero-medial rugulose area; mesopleuron rugulose, swollen shiny area postero-medially with carinae running antero-posteriorly across dorsal half of shiny area; propodeum rugose, median carina complete. Metasoma: first and second metasomal tergites rugocostate, median carina complete on both tergites, apical width of first tergite slightly greater than tergite length; third metasomal tergite rugulocostulate, median carina on basal $2 / 3$ of tergite; fourth metasomal tergite finely rugulose-areolate basally becoming coriaceous apically.

Male. Unknown.

Biology. Host unknown

Distribution. known only from type locality in Okanogan County, Washington.

Comments. Aleiodes okanoganensis is similar to A. wyomingensis, A. shenefelti, A. khalafi, and A. cultrarius. A. okanoganensis can be distinguished from all of these species by its orange coloration, in contrast to honey yellow in the others. It can be distinguished from $A$. wyomingensis by median carina entire on second metasomal tergite and present basally on third metasomal tergite, in contrast to median carina incomplete on second metasomal tergite and absent on third metasomal tergite in A. wyomingensis. In A. okananoganensis, the fourth metasomal tergite has rugulose areolate sculpturing, in contrast to coriaceous sculpturing on fourth metasomal tergite in A. wyomingensis. A. okanoganensis can be distinguished from $A$. shenefelti and $A$. khalafi by first metasomal tergite length shorter than 
apical width, in contrast to first metasomal tergite length longer than apical width in $A$. shenefelti and in $A$. khalafi females. Rugulose-areolate sculpturing of fourth metasomal tergite in A. okanoganensis contrasts with rugulose sculpturing in $A$. khalafi and coriaceous sculpturing in A. shenefelti. A. okanoganensis can be distinguished from $A$. cultrarius by mesosternum black in contrast to yellow in A. cultrarius, and by fourth metasomal tergite sculpturing finely rugulose-areolate in contrast to coriaceous in A. cultrarius.

Etymology. This species is named after the Washington county in which the holotype specimen was found.

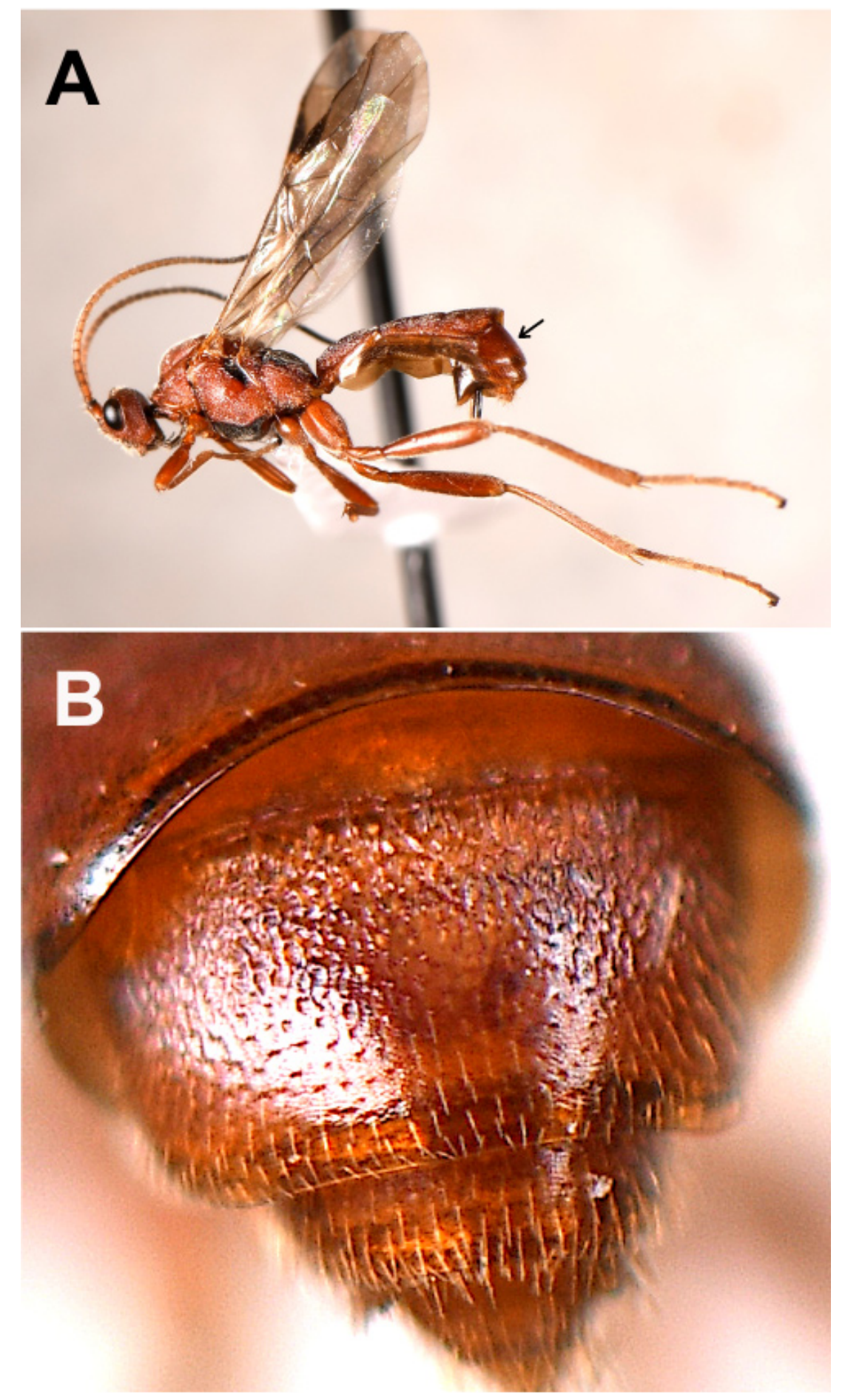

FIGURES 9, 10. Aleiodes okanoganensis (female) NEW SPECIES. Figure 9. Habitus. Note dark pigmentation on propodeum and venter of mesothorax. Figure 10. Fourth metasomal tergite. Note that it is sculptured and much larger than succeeding tergites. These character states together are unique to species in the Aleiodes coxalis (Spinola) species-group. Punctations in apical half are setal pits. 
TABLE 3. Characters and character states useful for distinguishing similar $A$. coxalis-group species. Bolded character states are most useful for distinguishing species with those characters from other closely similar species.

\begin{tabular}{|c|c|c|c|c|c|}
\hline Character & A. wyomingensis & A. shenefelti & A. cultrarius & A. khalafi & A. okanogansis \\
\hline Body color & $\begin{array}{l}\text { Honey yellow and } \\
\text { black }\end{array}$ & Honey yellow & Honey yellow & Mostly orange & $\begin{array}{l}\text { Mesosternum } \\
\text { black, propodeum } \\
\text { mostly black }\end{array}$ \\
\hline $\begin{array}{l}\text { No. antenno- } \\
\text { meres }\end{array}$ & 33 & $45-50$ & 41 & 52 & 47 \\
\hline $\begin{array}{l}\text { Propodeum me- } \\
\text { dian carina }\end{array}$ & Complete & Complete & Complete & Incomplete & Complete \\
\hline $\begin{array}{l}\text { Length/width } \\
\text { first metasomal } \\
\text { tergite }\end{array}$ & Less than 1 & Greater than 1 & Less than 1 & Greater than 1 & Less than 1 \\
\hline $\begin{array}{l}\text { Metasomal } \\
\text { median carina: } \\
\text { second tergite }\end{array}$ & Incomplete & Complete & Complete & Complete & Complete \\
\hline $\begin{array}{l}\text { Metasomal } \\
\text { median carina: } \\
\text { third tergite }\end{array}$ & Absent & Complete & Complete & Incomplete & Incomplete \\
\hline $\begin{array}{l}\text { Metasomal } \\
\text { median carina: } \\
\text { fourth tergite }\end{array}$ & Absent & Complete & Complete & Incomplete & Incomplete \\
\hline $\begin{array}{l}\text { Sculpturing } \\
\text { fourth tergite }\end{array}$ & Coriaceous & Coriaceous & Coriaceous & Rugulose & $\begin{array}{l}\text { Rugulose - are- } \\
\text { olate }\end{array}$ \\
\hline
\end{tabular}

\section{Aleiodes quasiburrus Fortier, NEW SPECIES}

(Figures 11, 12)

Holotype. §’ WASHINGTON, Okanogan County, west of Omak Lake, 48¹8'07'N; 119²6'41'”, June 1-10, 2020, J. Fortier. Deposited in USNM.

Male. Body color: Body bicolored, head, antennae, maxillary and labial palps entirely black except sometimes with yellow-orange on sides of face adjacent to eyes; mandibles with orange; mesosoma entirely black; coxae and trochanters of all legs black; first 3 metasomal tergites variable, usually with base of first tergite and apex of third tergite black or infumate, tergites otherwise yellow-orange, sometimes with first 3 tergites entirely yellow-orange, sometimes with first tergite mostly black or infumate; tergites 4-6 black; wings hyaline, fore wing veins light brown basally becoming dark brown or black apically, base of 1RS usually yellow-orange, hind wing veins light brown, sometimes darker apically. Body length: 5.9 - $6.3 \mathrm{~mm}$; Forewing length: $5.0 \mathrm{~mm}$. Head: ocellar diameter smaller than ocell-ocular distance; 52 flagellomeres, except for 2 basal flagellomeres all flagellomeres with length about equal to width; malar space about 1.3 as wide as base of mandible; face rugose-areolate; frons and vertex rugose. Legs: hind coxa shiny with transverse carinae dorsally, tarsal claws not pectinate, inner tibial spur of hind leg $1 / 3$ length of basal tarsomere. Wings: fore wing vein r 0.6 length of 3RSa, second submarginal cell trapezoidal, 3RSa 0.7 length of $2 \mathrm{M}$, vein $1 \mathrm{cu}-\mathrm{a}$ distal of $1 \mathrm{M}$ by a distance greater than length of 1cu-a, hind wing RS parallel to R1 for basal half of length, bending slightly posteriorly, marginal cell widening in apical half, m-cu spectral or faintly infumate. Mesonotum: pronotum rugose; mesonotum punctate, mesopleuron rugose except punctate medially; propodeum rugose, median carina absent. Metanotum: first and second metasomal tergites rugocostate, costae distinct; third metasomal tergite carinate on basal $3 / 4$, sometimes entirely, median carina either very faintly distinct from other carinae or absent.

Female. unknown.

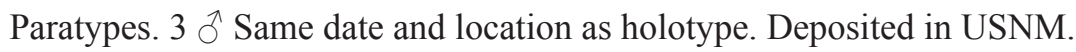




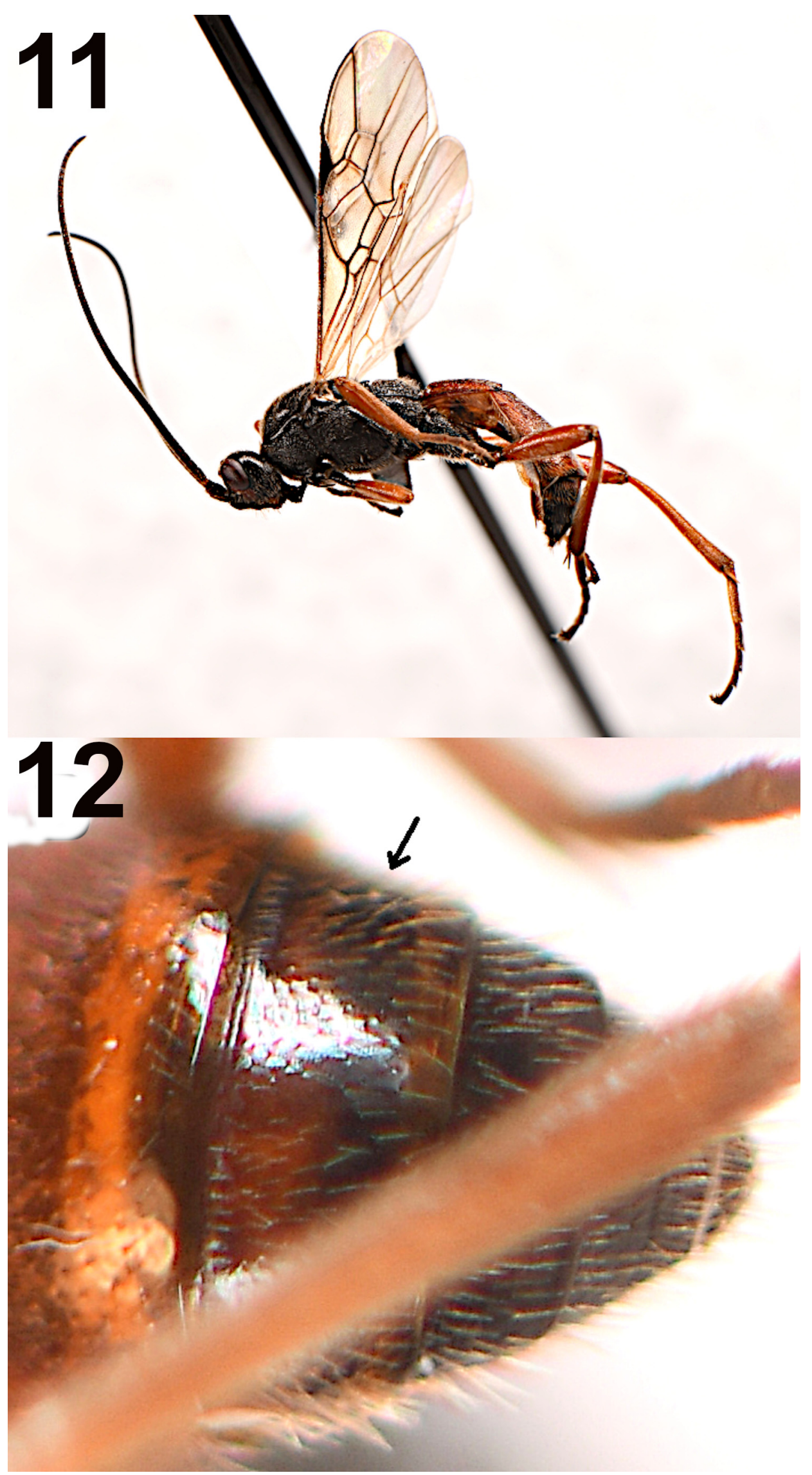

FIGURES 11, 12. Aleiodes quasiburrus (male) NEW SPECIES. Figure 11. Habitus. Figure 12. Fourth metasomal tergite (arrow). Note that it is only slightly larger than succeeding tergite, shiny and unsculptured except for setal pits, unlike Aleiodes coxalis (Spinola) species-group species. 


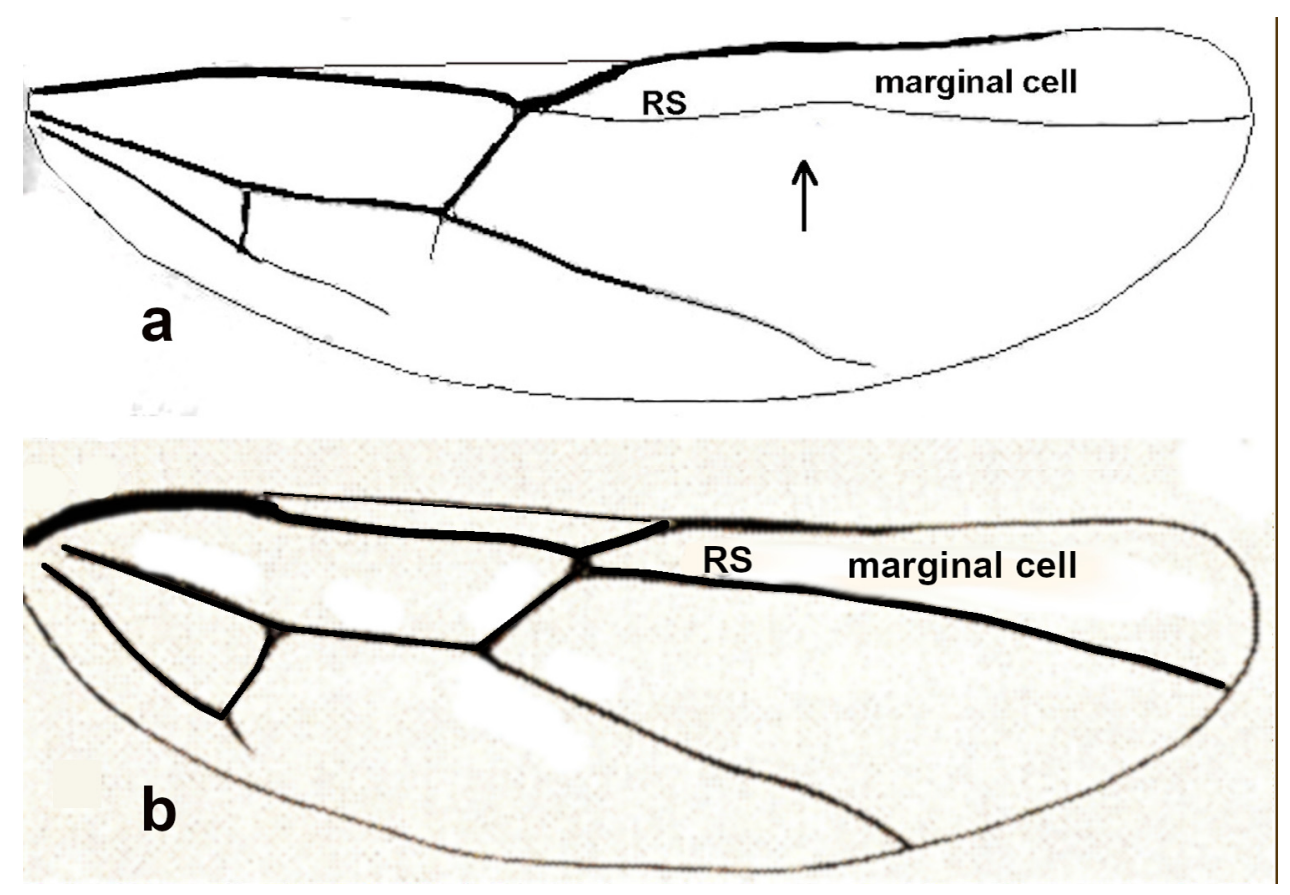

FIGURE 13. Variation in shapes of hind wing vein RS in Aleiodes species. a. Vein RS sinuate, arching anteriorly at middle (arrow). Marginal cell narrowest in middle. This character state is found in Aleiodes coxalis (Spinola) species group species, but not found in Aleiodes gasterator (Jurine) species-group species. b. Vein RS either straight or angling posteriorly in apical half; not sinuate. Marginal cell not narrowest in middle. This character state is found in Aleiodes gasterator (Jurine) species-group species, such as Aleiodes quasiburrus NEW SPECIES, but not in Aleiodes coxalis (Spinola) species-group species such as Aleiodes khalafi NEW SPECIES and Aleiodes okanoganensis NEW SPECIES.

Biology. Host unknown

Distribution. Known only from type location in Okanogan County. Washington.

Comments. Aleiodes quasiburrus is similar in appearance to males of A. burrus Cresson and to A. harrimani (Ashmead). It can be distinguished from A. burrus by the first metasomal tergite with distinct costae rather than entirely rugose as in $A$. burrus, and by the absence of a complete median carina on the propodeum in contrast to median carina complete in A. burrus. A quasiburrus can be distinguished from $A$. harrimani by long malar space, twice as long as mandible basal width as opposed to shorter malar space in $A$. harrimani, and all legs with black coxa and trochanter as opposed to only hind coxa black in A. harrimani.

Etymology. The specific name is from the Latin quasi for "similar to" and burrus, which is the specific name for an Aleiodes species to which this species is most similar.

\section{Discussion}

The new Aleiodes species described here fall into two previously described species-groups. Species-groups as used here are species that share a unique suite of common morphological characteristics not shared by other species within a genus (Fortier and Shaw 1999). A. khalafi and A. okanoganensis fall within the Aleiodes coxalis Spinola species group. This group is defined by the enlarged, sculptured fourth metasomal tergite (Figures 7, 8, 10) in combination with hind wing RS vein recurved (Figure 13a) (Shaw et al. 2006).

A. quasiburrus falls into the Aleiodes gasterator (Jurine) species-group. This group is defined by small ocelli, marginal cell of the hind wing gradually widening to the wing apex (Figure 13b), soma usually unicolored yellow or orange, and malar space longer than the basal width of the mandible (Marsh and Shaw 2001). This study includes six male $A$. quasiburrus specimens which displayed the above character states, except that the body was bicolored black and orange instead of unicolored. In one of the other A. gasterator species group species, A. burrus Cresson, the male is typically bicolored in a pattern similar to A. quasiburrus males, unlike the unicolored $A$. burrus female 
(Shaw 2006). The malar space was longer than the basal width of the mandible in all but two specimens in which the malar space length was equal to the mandibular basal width. The ratio of malar space length/basal mandibular width ranged from 1.6 to 1.0 .

New distribution records for species are vital for constructing hypotheses concerning the historical biogeography of a species, as well as for discovering the extent of variation in morphology and also in host utilization over the parasitoid's range. New understanding of the diversity and autecology within the parasitoid guild in an ecosystem contributes to greater overall understanding of the ecosystem, and may lead to economically significant new discoveries, such as finding that a given parasitoid may be beneficial to humans by suppressing population density buildups of an agricultural or forest pest species.

If all 13 Aleiodes species reported here from Washington State and nearby Inland Northwest areas were indeed to represent all Inland Northwest Aleiodes species, new species reported here would account for $23 \%$ of all presently documented Aleiodes species in this area. However, given that ranges of two previously described species are reported in the Inland Northwest for the first time here, it seems probable that more extensive investigation of the Inland Northwest will uncover much greater Aleiodes diversity in the region. Almost certainly this is also true for other small hyper-diverse Hymenoptera in the Inland Northwest.

\section{References}

Delfin-Gonzalez, H. \& Wharton, R.A. (2002) Distribution of species and species-groups of Aleiodes (Hymenoptera: Braconidae) in Mexico. Folia Entomologia Mexicana, 41 (2), 215-227. https://doi.org/10.7550/rmb.32000

Fortier, J.C. \& Shaw, S.R. (1999) Cladistics of the Aleiodes lineage of the subfamily Rogadinae (Hymenoptera: Braconidae). Journal of Hymenoptera Research, 8 (2), 204-237. https://doi.org/10.1080/0022293031000155278

Fortier, J.C. (2009) A revision of the Tetrasphaeropyx lineage of the genus Aleiodes Wesmael (Hymenoptera: Braconidae: Rogadinae). Zootaxa, 2256 (2256), 1-126. https://doi.org/10.11646/zootaxa.2256.1.1

Harris, R.A. (1979) A glossary of surface sculpturing. Occasional Papers in Entomology, 28, 1-33.

Huber, J. \& Sharkey, M. (1993) Chapter 3. Structure. In: Goulet, H. \& Huber, J.T. (Eds.), Hymenoptera of the World: An Identification Guide to Families. Agriculture Canada Publication 1894/E. Research Branch, Agriculture Canada, Ottawa, pp. 13-59.

Jones, O.R., Purvis, A., Baumgart, E. \& Quicke, D.L.J. (2009) Using taxonomic revision data to estimate the geographic and taxonomic distribution of undescribed species richness in the Braconidae (Hymenoptera: Ichneumonoidea). Insect Conservation and Diversity, 2 (3), 204-212. https://doi.org/10.1111/j.1752-4598.2009.00057.x

Marsh, P.M. \& Shaw, S.R. (2001) Revision of North American Aleiodes Wesmael (Part 6): The gasterator (Jurine) and unipunctator (Thunberg) species-Groups. Proceedings of the Entomological Society of Washington, 103 (1-2), 291-307. https://doi.org/10.13001/uwnpsrc.2012.3935

Shaw, S.R. (1997) Subfamily Rogadinae s.s. In: Wharton, R. A., Marsh, P. M. \& Sharkey M.J. (Eds.), Manual of New World Genera of the Family Braconidae (Hymenoptera). Special Publication of the International Society of Hymenopterists, Washington, D.C., pp. 403-408.

Shaw, S.R., Marsh, P.M. \& Fortier, J. (2006) Revision of Nearctic Aleiodes Wesmael (Part 8): the coxalis (Spinoza) speciesgroup. Zootaxa, 1314 (1), 1-30. https://doi.org/10.11646/zootaxa.1314.1.1

Shaw, S.R. (2006) Aleiodes wasps of eastern forests: a guide to parasitoids and associated dead caterpillars. Forest Health Technology Enterprise Team (FHTET), Morgantown, West Virginia. Available from: https://www.fs.fed.us/foresthealth/technology/pdfs/AleiodesBookWeb.pdf (accessed 5 May 2021)

Shaw, S.R., Marsh, P.M. \& Talluto, M.A. (2013) Revision of the American Aleiodes (Part 9): The pallidator (Thunberg) speciesgroup with description of two new species (Hymenoptera: Braconidae, Rogadinae). Zootaxa 3608 (3), $208-214$. https://doi.org/10.11646/zootaxa.3608.3.4

Shenefelt, R.D. (1978) Braconidae 10. Braconinae, Gnathobraconinae, Mesostoinae, Pseudodicrogeniinae, Telengainae, Ypsistocerinae plus Braconidae in general, major groups, unplaced genera and species, 1978. In: Achterberg, C. van \& Shenefelt, R.D. (Eds.), Hymenopterorum Catalogus. Nova Editio. Pars 15. Dr. W. Junk, The Hague, pp. 1425-1872.

Shimbori, E.M. \& Shaw, S.R. (2015) A revision of the New World species of the Aleiodes compressor species group (Hymenoptera: Braconidae: Rogadinae). The Canadian Entomologist, 147 (6), 665-673.

https://doi.org/10.4039/tce.2015.9 